\title{
Teachers' Questions and Feedbacks in EFL Classrooms
}

\author{
Cheng-hua Hsiao \\ Department of Foreign Languages and Literature, National Ilan University \\ No.1, Shennong Rd. Sec. 1, Yilan City, Yilan County 260, Taiwan (R.O.C.) \\ Tel: 886-3-9317890Ｅ-mail: chhsiao@niu.edu.tw
}

Received: December 7, 2017 Accepted: December 19, 2017 Published: December 20, 2017

doi:10.5296/ijele.v5i2.12337 URL: https://doi.org/10.5296/ijele.v5i2.12337

\begin{abstract}
Guided questions are crucial in teaching listening courses because they lead students to focus on the critical parts of the course. How teachers ask questions affects their students listening comprehension and output. The purpose of this study was to study the types of teacher questions and the feedback offered by teachers in two listening classes. Two teachers were selected as the subjects: one had taught English for seven years, and the other was a graduate student on an English language teaching master's program. Both subjects were teaching an English listening class as a teaching demonstration that was part of their graduate course. Three research questions were raised in this study: (1) What questioning models did the teachers use in the listening classes? (2) What types of questions were asked in these classes? and (3) What were the functions of the teachers' feedback on students' responses? The findings indicated that both teachers adopted a process approach in their teaching of listening classes. The questions that the experienced teacher asked with highest frequency were Wh-questions, whereas the intern asked Yes/No questions. The experienced teacher often used the feedback types of comprehension checking and expansion, whereas the intern often provided evaluations and used repetition in feedback.
\end{abstract}

Keywords: Questioning strategy, Interaction analysis, Classroom discourse 


\section{Introduction}

In the teaching of listening courses, guided questions are crucial for leading students to focus on the critical parts of the course. When students are not clear on what they hear, teaching interventions are typically needed. Teacher's skillful use of various questions and formats can guide students to develop effective listening habits. Therefore, this study intended to examine the question format of experienced and less experienced teachers to obtain insights into questioning strategies.

Teachers' questions have long attracted considerable attention in content classes, and their value cannot be ignored. Recently, L2 classroom process researchers have turned their focus toward the effects of questions in language classrooms, especially English as a Foreign Language (EFL) classrooms. However, discourse in EFL listening classes is seldom investigated, and listening classes, with their special characteristics, have not been researched. Because negotiations and interactions are promoted during second-language acquisition, more attention must be paid to the discourse genre and quality of communication between teachers and students in EFL listening classrooms. Three research questions were thus posed:

1. What questioning models were used in the subjects' listening classes?

2. What types of questions were asked in these classes?

3. What were the functions of the teachers' feedback on students' responses?

\section{Literature Review}

\subsection{Interaction Analysis}

Interaction analysis has drawn sociolinguists' attention. Most cognitive psychologists would not position their domain of inquiry on the basis of socially situated meanings. However, interaction analysis is a necessary interpretative move if the relationship between the processes of teaching and learning is to be explored for further insight into the relationship between the form and functions of language.

Conversations are chosen for analysis because they provide instances of interpersonal and interactional nature of communication. Sinclair and Coulthard (1975) studied initiations and responses in conversations between teacher and students in classroom. On the other hand, Flecther (1985) studied a child's initiation and response in a child-mother's talk. Among interaction analysis, studies of questions have attracted discourse analysts' attentions. Questions in some circumstances serve as speech acts, such as requests for information, action, or help. Take children at a young age as examples, they have learned the tacit differences in questions in the form of proclamation and opposition, meaning that they acquire both literal and intended meanings from utterances.

Based on dialogic utterances rather than grammatical sentences, Bakhtin (1981, 1986) established a theory of language from social perspective. In this view of social communication, the unit of analysis for language studies relies on the utterances, which are defined by speakers turn changing. This school of thoughts shares his theoretical perspective 
on social nature of language, acknowledging that semantic content and grammatical form in words and sentence. But, meanings embedded in words and sentences are inherently social in nature. Vygotsky $(1986,1987)$ proposed the same idea that only speech has sense, meaning that meanings are acquired only through social use of language. Meaning is socially situated (Fairclough, 1989, 1992; Gee, 1990, 1992; Gumperz, 1982; Halliday, 1978; Halliday \& Hasan, 1989; Hymes, 1974; Lemke, 1990).

\subsection{Discourse Genres: IRE/IRF}

The pattern whereby a mother initiates a phrase from a book and her child fills in the space left open by her pause resembles what scholars of classroom discourse have termed Initiation-Response-Evaluation (IRE) (Cazden, 1986, 1988; Mehan, 1979) or InitiationResponse-Follow-up (IRF) (Sinclair \& Coulthard, 1975; Well, 1993) sequences.

Participating in a whole-class discussion involves a unique set of social roles, forms of discourse, and modes of activities, such as engaging in symbolic play with peers. There are a certain set of participation structure in every form of classroom activity. Participants are involved themselves in the activity socially and linguistically (Au, 1980; Erickson \& Shultz, 1981; Harness-Goodwin, 1990; O'Connor \& Michaels, 1999). Students in language classes are predetermined by what to say and how to say and when to say it. Learners must pay attention to various contextualization prompts to take part successfully in classroom discussions (Gumperz, 1982).

\subsection{Teaching Context}

In a traditional formal instruction context, there exists an authority center- the teacher-who dominates the class. Moreover, the content of the lesson is preplanned, and the teacher is expected to present the material according to the course schedule. Therefore, the teacher must maintain centralized attention to make the lesson proceed as planned (McHoul, 1978; Sinclair $\&$ Brazil, 1982). As a result, the turn-taking pattern in classrooms is highly structured and strictly controlled by the teacher (Allwright, 1988). Turns between the teacher and students are allocated by the teacher, forming a Teacher-Student-Teacher-Student pattern (Nong, 1993). Usually, the teacher who decides the topic and initiates the turn, and students are then given the floor to respond to the teacher's commands. Thereafter, the teacher takes back the turn.

Speakers habitually make clear to each other the boundaries of the opening section, the topic, and the closing section. The boundary markers take the form of articulatory gestures, such as "look," "well," and "OK."

As far as classroom discourse is concerned, it has a didactic purpose. Sometimes, the teacher's discourse takes various forms, which lead to different functions. For example, declarative utterances in the form of statements are made to provide information, whereas interrogative utterances in the form of questions are made to elicit responses from learners. Imperatives in the form of commands are employed to direct the content of speech. 


\subsection{Teacher Questioning}

Teachers' questions in content classes have long attracted substantial attention. Their value has also been identified. Recently, L2 classroom process researchers have investigated the effects of teachers' questions in language classrooms. Such questions serve more of a pedagogic function than a communicative function (Larsen-Freeman, 1980; Mehan, 1979; Sinclair \& Coulthard, 1975). Instead of seeking information from students, the teacher asks students questions to elicit their verbal performance and reveal their knowledge or lack of knowledge of the content. Naturally, teachers do not ask questions because they wish for the answer, but because they would like to check whether the students know the answer. With this purpose, teachers may provide feedback on students' responses.

Studies on teachers' questioning strategies have focused on the classification of questions based on cognitive processes (Gall, 1970). However, the weakness of such classification is that these processes are inferential constructs. Some researchers classify teachers' questions on the basis of whether the teacher knows the answer, as in the case of closed questions versus open questions (Mitchell, 1985), or its alternative, display questions versus referential questions (Long \& Sato, 1983). Display or closed questions refer to questions to which the answers are known by the teachers. By contrast, referential or open questions have answers that are not known by the teacher.

Following the trends of research into teachers' questioning, second language researchers have turned their attention toward teachers' questioning in language classrooms (Brock, 1986; Long \& Sato, 1983; Pica \& Long, 1986). Long and Sato (1983) investigated the forms and functions of teachers' questions in English as a Second Language (ESL) classrooms and compared their findings with questioning behavior in native speaker-nonnative speaker conversation outside the classroom. They revised Kearsley's (1976) categories and explored the use of display questions, referential questions, and questions for comprehension checks, confirmation checks, and clarification requests. Their findings revealed that ESL teachers used more statements and fewer questions than native speakers in conversation; in addition, the ESL teachers raised more display questions and fewer referential questions. Furthermore, the ESL teachers used more questions to check learners' comprehension and fewer questions to check for confirmation than native speakers in conversation. Lastly, the ESL teachers emphasized form over meaning and accuracy over communication (Long \& Sato, 1983).

To determine the effects of various types of questions in L2 learning, Brock (1986) explored the relationship between ESL teachers' use of referential and display questions and learners' language production. A crucial finding was that learners produce extended and more syntactically intricated responses to referential than to display questions. This implies that when responding to referential questions, learners produce more target language. As a result, more comprehensible output was obtained, and second language learning was facilitated.

\subsection{Feedback}

Chaudron (1988) and Allwright and Bailey (1991) addressed the value of feedback in language learning. Teachers use feedback to check learners' understanding, inform learners of 
their errors in the target language, and direct learners' topic development. By providing feedback, teachers may either affirm or negate learners' hypotheses regarding the target language. From a linguistic perspective, language learners form hypotheses on the grammatical rules of the target language, test these against input data, and then modify them accordingly (Ellis, 1994).

\section{Methods}

\subsection{Data Collection}

The data source used in this study was an audio file and a video file of two micro classes held during the first semester of an academic year as part of a listening course. The two teachers taught English listening classes. Authorization for recording, videotaping, and transcribing the content of the two classes was provided by the two teachers. These two teachers were carefully chosen because of their teaching experiences. One teacher had taught English for more than seven years, and the other was an intern. The listening materials they chose to teach were selected in similar fashion. One material was North Star, which is aimed at High Intermediate learners, and the other was Listen for It, targeted at elementary learners.

\subsection{Setting, Participants, and Activities}

Before the two teachers began teaching, they wrote lesson plans to facilitate this study's understanding of the format of their classes. The class taught by the intern comprised 12 students. The focus of the lesson was the doctor-patient relationship. The lesson consisted of three listening activities. Each activity included a listening session and a follow-up exercise. The three activities were conducted within a 37-minute teaching session. The class taught by the experienced teacher comprised 15 students. The focus of the lesson plan was on jobs. This teacher's lesson plan had four activities. Because of time constraints, the teacher only put the first activity into practice.

\subsection{Coding Categories}

To analyze the examples of classroom discourse, I transcribed approximately 37 minutes (time 0:00-37:23) of the intern's class and 34 minutes (time 0:00-34:20) of the experienced teacher's class.

To facilitate analysis, I coded several aspects of the classroom discourse, and another doctoral student in English language teaching coded the same materials. The interrater reliability was 95.3\%, which indicates substantial agreement between the two coders. The first set of codes applied was crucial to the reading of the transcription. Who was speaking-whether it was the teacher, a student, or multiple students - was coded respectively as T, S, and Ss. The second set of codes referenced the function of the teacher's feedback, which was classified as evaluation (E) of students' contributions, repetition/rephrase (R) of a student's response, the teacher's nonresponse (NR), clarification/correction (C) by the teacher of a student's response, expansion/addition (Ex) to the response, comprehension checking (Com), or a request for clarification (Req). 


\section{Macrothink}

\subsection{Definition of Terms}

\subsubsection{Types of Questions}

(1) Wh-Question: This refers to questions containing Wh words in English: what, when, why, how, where, and who. For example,

\section{Excerpt 1}

T: How do you feel about it?

S: I feel upset.

(2) Yes/No Question: This refers to a question that asks for a confirmation or denial of the statement embedded in the question. An inversion of the subject and auxiliary in the sentence forms a Yes/No question. Yes/No questions are sometimes asked in the form of increasing the intonation of a statement. For example,

\section{Excerpt 2}

T: Is he an intern doctor?

S: No, he is old.

Excerpt 3

T: Finished. Eveline?

S: Finished.

(3) Alternative Question: This is a question that includes the marker "or," the objective of which is to have listeners make a choice. For example,

\section{Excerpt 4}

T: Do you all get that? Or not?

S: [students nod their heads]

(4) Rhetorical Question: This type of question is asked only for effect, without expecting a response.

\section{Excerpt 5}

T: ...buy within this circle. How about actors? They travel as part of their jobs.

Now, we are going to listen to four conversations....

(5) Incomplete Question: This refers to questions that are incomplete. Incomplete questions are sometimes asked to allow students to take the floor. Feedback is provided after an incomplete question is raised.

\section{Excerpt 6}

T: Flight attendants and...?

S: Business people.

T: Good.

(6) Textbook Question: Questions listed in the textbook.

\section{Excerpt 7}

T: You have to focus on these four questions: "What medical problem did this person have?"...The second, "How did the doctor treat this patient?" And then, "Was the experience satisfactory?" "Did the patient try an alternative treatment?"

\section{Findings}

\subsection{Models in the Two Listening Classes}

In this study, I used the models proposed by Flowerdew and Miller (2005) to examine the experienced teacher's and intern's questions while teaching a listening class. The models are 
presented in Tables 1 and 2 according to the implementation of the lesson plan in the experienced teacher's and intern's classes.

Table 1. Experienced teacher's model for listening class

\begin{tabular}{|l|l|l|}
\hline Phases & Functions & Activities \\
\hline Prelistening & Set Scene & $\begin{array}{l}\text { Match jobs with pictures. } \\
\text { Ask questions about jobs. }\end{array}$ \\
\hline Focus Qs & $\begin{array}{l}\text { Ask which of the people in the pictures do the things } \\
\text { in certain conditions. } \\
\text { Ask questions about the characteristics of certain jobs. }\end{array}$ \\
\hline While-listening & $\begin{array}{l}\text { Sistening } \\
\text { Comprehension }\end{array}$ & $\begin{array}{l}\text { Number the pictures 1 to 4 } \\
\text { Teacher explained the differences between full-time } \\
\text { and part-time jobs and weekday and weekend jobs. } \\
\text { Listen again. Complete the information about each } \\
\text { job. Check part-time or full time and write in days. }\end{array}$ \\
\hline Postlistening & $\begin{array}{l}\text { Focus Qs } \\
\text { Evaluation } \\
\text { 2. Production games }\end{array}$ & $\begin{array}{l}\text { 1. Check students' answers. } \\
\text { 2. Game: 20 questions. } \\
\text { Each student writes 2 jobs on a piece of paper. All }\end{array}$ \\
\hline
\end{tabular}

Table 2. Intern's model for listening class

\begin{tabular}{|c|c|c|}
\hline Phases & Functions & Activities \\
\hline Prelistening & Set Scene & $\begin{array}{l}\text { Ask students to recall their experience when they see a } \\
\text { doctor. } \\
\text { Pair up discussing a picture on the worksheet. } \\
\text { Students share their experiences. } \\
\text { Focus on the behaviors of doctors }\end{array}$ \\
\hline Input & Spoken Text & Listen to the introduction of the radio show. \\
\hline While-listening & $\begin{array}{l}\text { Listening } \\
\text { Comprehension }\end{array}$ & See the checked answers on the worksheet \\
\hline Postlistening & Discussion & Pair up discussing the behaviors of doctors. \\
\hline Prelistening & Focus Strategies & $\begin{array}{l}\text { Have students read through the questions aloud once. } \\
\text { Teaching listening strategies: how to get the main idea. } \\
\text { Demonstrate how to listen to the interview for four } \\
\text { questions. }\end{array}$ \\
\hline Input & Spoken Text & The conversation is played twice. \\
\hline While-listening & Listening & During the second time, the teacher plays part of the \\
\hline
\end{tabular}




\begin{tabular}{|l|l|l|}
\hline & Comprehension & $\begin{array}{l}\text { conversations and read the scripts time and again in order } \\
\text { to check answers on the worksheet. }\end{array}$ \\
\hline Prelistening & Set Scene & Explain how to fill the chart according to the questions. \\
\hline Input & Spoken Text & Listen to the text. \\
\hline While-listening & & See the written answers on the worksheet. \\
\hline
\end{tabular}

As revealed in the two tables, the experienced teacher's teaching model is as follows: prelistening $\rightarrow$ input $\rightarrow$ while-listening $\rightarrow$ postlistening. This forms a complete listening cycle. The topic of full-time or part-time jobs was discussed in the first listening task. Learners were introduced to the definitions of full-time and part-time jobs and learned to distinguish the types of jobs mentioned in the four conversations. In the postlistening phase, the experienced teacher employed a game called "twenty questions" "for the prelistening activity. Students referred to "work at night," "need good communication skills," "work outdoors," "wear a uniform," and "travel as part of the job" as starting points to elicit a Yes/No response from the teacher and guess the answer.

The intern used the same model for her listening lesson with one variation: she used three listening inputs, which were all related to the doctor-patient relationship. However, only the first input, with a prelistening activity held in advance, was followed by while-listening and postlistening activities. The other two inputs lacked a postlistening activity. Because of time constraints, the intern avoided the postlistening activities to ensure she could execute the entire lesson plan.

\subsection{Types of Questions used by Both the Experienced Teacher and Intern}

\subsubsection{Question Types}

Six types of question were found in the teachers' questions, and they are listed in Table 3.

Table 3. Frequency of each question type used by the experienced teacher and intern in listening classes

\begin{tabular}{lccc}
\hline Question Types & Experienced Teacher & Intern & Total \\
\hline WH-Q & 52 & 12 & 64 \\
Yes/No Q & 14 & 31 & 45 \\
Alternative Q & 0 & 1 & 1 \\
Rhetorical Q & 0 & 2 & 2 \\
Incomplete Q & 7 & 0 & 7 \\
Textbook Q & 4 & 10 & 14 \\
Total & 78 & 56 & 133 \\
\hline
\end{tabular}

The type of question most frequently asked by the experienced teacher was wh-questions. By contrast, the intern most frequently asked Yes/No questions.

\footnotetext{
1 "Twenty questions" was a game played in this class as a postlistening activity. Students write two jobs on two slips of paper. The slips are collected and students try to guess those jobs by asking Yes/No questions.
} 
Table 4. Percentage of question types used by the experienced teacher and intern in listening classes

\begin{tabular}{lccc}
\hline Question Types & Experienced Teacher \% & Intern \% & Total \% \\
\hline WH-Q & 67.53 & 21.43 & 48.12 \\
Yes/No Q & 18.18 & 55.36 & 33.83 \\
Alternative Q & 0.00 & 1.79 & 0.75 \\
Rhetorical Q & 0.00 & 3.57 & 1.50 \\
Incomplete Q & 9.09 & 0.00 & 5.26 \\
Textbook Q & 5.19 & 17.86 & 10.53 \\
\hline Total & 100.00 & 100.00 & 100.00 \\
\hline
\end{tabular}

Table 4 displays the percentage of questions asked by the experienced teacher and intern that were of each type. The largest proportion of all questions asked by the experienced teacher was wh-questions, at $67.53 \%$. Yes/No questions were also asked but had a smaller percentage of only $18.18 \%$. By contrast, the intern used Yes/No questions most often, at $55.36 \%$ of all questions asked. The second and third most frequent types of question asked by the intern were wh- and textbook questions, at $21.43 \%$ and $17.86 \%$, respectively.

Table 5. Distribution of question types in the three phases of the listening class conducted by the experienced teacher

\begin{tabular}{lcccc}
\hline Question Types & Prelistening \% & While-listening \% & Postlistening $\%$ & Total \% \\
\hline WH-Q & 58.14 & 81.25 & 50.00 & 67.53 \\
Yes/No Q & 18.60 & 15.63 & 50.00 & 18.18 \\
Alternative Q & 0.00 & 0.00 & 0.00 & 0.00 \\
Rhetorical Q & 0.00 & 0.00 & 0.00 & 0.00 \\
Incomplete Q & 13.95 & 3.13 & 0.00 & 9.09 \\
Textbook Q & 9.31 & 0.00 & 0.00 & 5.19 \\
\hline Total & 100.00 & 100.00 & 100.00 & 100.00 \\
\hline
\end{tabular}

For further analysis, I examined the distribution of each question type in the three phases of the listening class. For the experienced teacher, wh-questions were asked with high frequency in the prelistening phase, at $58.14 \%$ of all questions. Yes/No questions, incomplete questions, and textbook questions ranked second, third, and fourth, at $18.60 \%, 13.95 \%$, and $9.31 \%$, respectively. In the while-listening phase, wh-questions were again asked frequently. Their percentage was the highest among the three phases, at $81.25 \%$. In the postlistening phase, only two questions were asked-one was a wh-question, and the other was a Yes/No question.

Table 6. Distribution of question types in the three phases of the listening class conducted by the intern

\begin{tabular}{lllll}
\hline Question Types & Prelistening \% & While-listening \% & Postlistening \% & Total \%
\end{tabular}




\begin{tabular}{lrrrr} 
WH-Q & 20.00 & 11.11 & 42.86 & 21.43 \\
Yes/No Q & 50.00 & 88.89 & 42.86 & 55.36 \\
Alternative Q & 0.00 & 0.00 & 14.28 & 1.79 \\
Rhetorical Q & 5.00 & 0.00 & 0.00 & 3.57 \\
Incomplete Q & 0.00 & 0.00 & 0.00 & 0.00 \\
Textbook Q & 25.00 & 0.00 & 0.00 & 17.86 \\
\hline Total & 100.00 & 100.00 & 100.00 & 100.00 \\
\hline
\end{tabular}

Unlike the experienced teacher, the intern asked more Yes/No questions and textbook questions than wh-questions in the prelistening phase. Their percentages were 50\%, 25\%, and $20 \%$, respectively, of all questions asked. Yes/No questions also occupied the largest proportion of questions asked in the while-listening phase. In the postlistening phase, fewer questions were asked: three wh-questions, three Yes/No questions, and one alternative question, occupying $42.86 \%, 42.86 \%$, and $14.28 \%$, respectively, of all questions asked.

Table 7. Distribution of questions in the three phases of the listening classes by both teachers

\begin{tabular}{lcccc}
\hline Phase & Prelistening $\%$ & While-listening $\%$ & Postlistening $\%$ & Total\% \\
\hline Experienced Teacher & 55.84 & 41.56 & 2.60 & 100 \\
Intern & 71.43 & 16.07 & 12.50 & 100 \\
Total & 62.41 & 30.82 & 6.77 & 100 \\
\hline
\end{tabular}

In summary, the questions asked by the experienced teacher in the prelistening phase amounted to $55.84 \%$ of all questions asked in their class; $41.87 \%$ were asked in the while-listening phase, and $2.60 \%$ were asked in the postlistening phase. Conversely, the questions asked by the intern in the prelistening phase amounted to $71.43 \%$ of all questions asked, whereas $16.07 \%$ were asked in the while-listening phase, and $12.50 \%$ were asked in the postlistening phase. The intern asked the most of her questions in the prelistening phase, with much fewer questions in the while-listening and postlistening phases. The experienced teacher also asked the most questions in the prelistening phase, but the percentages are averagely distributed between the prelistening and while-listening phases.

\subsection{Function Types in IRE/IRF}

In scrutinizing the content of the exchanges between the teacher and students, I found either IRE or IRF sequences in classrooms. Such sequences are composed of an "Initiation move" by the teacher, followed by a "Response move" from students, followed by a "Feedback move" or "Evaluation move" based on the students" responses.

Table 8. Functions and percentages of both teachers' comments in feedback turns

\begin{tabular}{lcc}
\hline \multicolumn{1}{c}{ Functions } & $\begin{array}{c}\text { out of experienced teacher } \\
\text { comments in feedback turns \% }\end{array}$ & $\begin{array}{c}\text { out of intern comments in } \\
\text { feedback turns \% }\end{array}$ \\
\hline Repetition/rephrase (R) & 15.15 & 47.06 \\
Evaluation (E) & 16.67 & 41.18
\end{tabular}


No response (NR) 2017, Vol. 5, No. 2

Expansion/addition (EX)

9.09

0.00

Clarification/correction $(\mathrm{C})$

22.73

11.76

Comprehension checking (Com)

4.55

0.00

Confirmation (Con)

28.79

0.00

Request for clarification (Req)

1.52

0.00

Total

1.52

0.00

100.00

100.00

Table 8 details the responses of the teachers to the students. For the experienced teacher, comprehension checking and expansion were the most common, at $28.79 \%$ and $22.73 \%$ of all feedback instances. Conversely, the intern gave feedback to students in the form of repetition and evaluation, accounting for $47.06 \%$ and $41.18 \%$ of all responses.

Table 9. Distribution of the functions of feedback in the three stages of teaching listening comprehension

\begin{tabular}{lcccccc}
\hline $\begin{array}{l}\text { Phase } \\
\text { Function }\end{array}$ & \multicolumn{2}{l}{$\begin{array}{l}\text { Pre-listening } \\
\text { Experienced Intern }\end{array}$} & \multicolumn{2}{c}{$\begin{array}{l}\text { While-listening } \\
\text { Experienced Intern }\end{array}$} & \multicolumn{2}{l}{$\begin{array}{l}\text { Post-listening } \\
\text { Experienced Intern }\end{array}$} \\
\hline $\begin{array}{l}\text { Repetition/ } \\
\text { rephrase (R) }\end{array}$ & 13.64 & 38.64 & 19.05 & 0.00 & 0.00 & 75.00 \\
$\begin{array}{l}\text { Evaluation (E) } \\
\text { No response (NR) }\end{array}$ & 22.73 & 46.15 & 4.76 & 0.00 & 0.00 & 25.00 \\
$\begin{array}{l}\text { Expansion/ } \\
\text { addition (EX) }\end{array}$ & 24.00 & 15.38 & 19.05 & 0.00 & 0.00 & 0.00 \\
$\begin{array}{l}\text { Clarification/ } \\
\text { correction (C) }\end{array}$ & 4.55 & 0.00 & 4.76 & 0.00 & 0.00 & 0.00 \\
$\begin{array}{l}\text { Comprehension } \\
\text { checking (Com) }\end{array}$ & 25.00 & 0.00 & 38.10 & 0.00 & 0.00 & 0.00 \\
$\begin{array}{l}\text { Confirmation (Con) } \\
\text { Request for }\end{array}$ & 0.00 & 0.00 & 4.76 & 0.00 & 0.00 & 0.00 \\
clarification (Req) & 0.00 & 0.00 & 0.00 & 0.00 & 100.00 & 0.00 \\
\hline Total & 100.00 & 100.00 & 100.00 & 100.00 & 100.00 & 100.00 \\
\hline
\end{tabular}

As indicated in Table 9, the experienced teacher's feedback in the prelistening stage mainly served as comprehension checking (25.00\%), expansion (24.00\%), and evaluation (22.73\%). By contrast, the intern's feedback functioned largely as evaluation (46.15\%) and repetition $(38.64 \%)$. However, in the while-listening stage, the experienced teacher asked questions to check the students' comprehension (38.10\%), expand students' responses (19.95\%), and repeat what students had said $(19.05 \%)$. The intern did not raise any questions in this phase; therefore, no feedback was given during this phase. For the postlistening phase, there was only one round of feedback, to request clarification from a student. The intern's feedback functioned mostly as repetition (75.00\%) in the final stage. 


\section{Discussion}

\subsection{Question Models in the Listening Classes}

According to Flowerdew and Miller (2005), the traditional teaching method for listening is to provide a spoken text and have the teacher ask relevant questions to test the learners' comprehension. In effect, learners may not be satisfied with their competence in listening to the oral text and constantly wish it to be replayed when they do not understand everything that is said. Without stating the objectives of the listening at the start, the learners' focus is on the repetition and completion of information in the oral text. This method is viewed as a "product approach."

Flowerdew and Miller (2005) also offered another model for teaching listening: instructors give students reasons to listen at the onset. Focus questions or strategies are provided so that learners can focus on the desired section or apply strategies they are introduced to in their listening. The message that learners identify from listening may also become part of the postlistening activity. This model, termed a "process approach," "begins to help learners to develop their skills and strategies for listening” (Flowerdew \& Miller, 2005).

\section{Excerpt 8 (Experienced teacher)}

T: How about a salesperson?

$\mathrm{S}$ : He sells things.

T: Yes, involves buying and selling things.

At the start of the exercise, the intern asked students to recall their experience of seeing doctors. This move was intended to motivate students to discuss their feelings about seeing a doctor.

\section{Excerpt 9 (Intern)}

T: ...didn't give you any eye contact, so have you experienced this kind of situation? How do you feel about that?...Any volunteers?

$\mathrm{S}$ : The doctor is inconsiderate.

In Excerpts 8 and 9, the teachers asked focused questions at the onset to elicit student responses and motivate students to pay attention to the theme of the lesson plan. The experienced teacher matched jobs with persons in the pictures on handouts and later asked who worked at night, whose jobs required them to have good communication skills, and so on, in the prelistening stage. These questions prepared the students to discuss the themes of the lesson.

\subsection{Question Types in the Three Phases of the Listening Classes}

The experienced teacher asked more wh-questions in the prelistening and while-listening stages. The intern asked more Yes/No questions in all three stages.

According to Sinclair and Brazil (1975), questions can have several forms. One form is intended to inform, whereas others involve adding new information to the topic that is being discussed. "Informing" requires the addressee only to acknowledge or provide evidence that they have received the information. By contrast, "eliciting" anticipates some contribution of information from the addressee.

When asking wh-questions, teachers do not generally begin with a closed class selection 
because the question seeks information. This type of question is more demanding than a Yes/No response, which reduces student response to a minimum that says no more than yes or no.

Yes/No questions are questions that allow for only one decision. The ideal response to a simple invitation to decide is supposedly "yes" or "no." If the addressee is indecisive, there is a secondary closed class of "maybe," "sometimes," "probably," and so on that the speaker is able to turn to in order to keep communication going. In these two listening classes, the teachers were concerned with maintaining as much control as possible, so they were likely to elicit answers to which the answers were known.

\section{Excerpt 10 (Experienced teacher)}

T: Can you tell me who, among the eight employees, works at night?

S1: The bartender.

S2: Sometimes, I said sometimes.

T: Who else works [works] at night?

S: The doctor.

T: Good.

S2: Flight attendants.

T: Good. Flight attendants work at night....

\section{Excerpt 11 (Intern)}

T: How do you feel about it? Do you feel upset or anything?

S: I feel...upset.

T: Upset. Very good.

In Excerpts 10 and 11, the elicitations are inclined toward explicit questions and answers. Certainly, both teachers are in a position to insist on the form of an answer. Even though a whole sentence is needed to answer a wh-question, learners were allowed to merely acknowledge information.

Excerpt 11 suits a test situation. What the teacher usually exploits was used as the test question. The convention is that the teacher's perspective is not revealed, and the student is required to make an extended response. The interrogative helps to obscure what the teacher thinks, and a situation is created that makes the student decide and then justify their decision. However, the student in this example failed to provide any further explanation of why they were upset. The teacher also failed to ask a follow-up question. Therefore, teachers' follow-up responses to their students' responses are of great value because they lead to better understanding of the quality of teacher-student interactions and the effects they have on the students.

\subsection{Question Functions}

In social discourse or natural conversation, the presence of an evaluation implies challenge or aggression. However, in classrooms, teachers are obliged to give feedback and to evaluate students' responses. Highly structured or severely controlled environments, such as classrooms, are reported to have few bilateral exchanges of information, leading to the scarcity of negotiation of meaning, and therefore, the communication is so-called "pseudocommunication" (Larsen-Freeman, 1980; Long, 1983; McTear, 1975). 
Excerpt 12 (Experienced teacher)

I T: How about a waiter? There is another word for waiter, but it refers to a female.

R Ss: Waitress.

F T: Good. Good job.

Excerpt 12 features a teacher-initiated question followed by a student's answer. The teacher's feedback served as comprehension checking.

\author{
Excerpt 13 (Experienced teacher) \\ I T: How about those who work [work] outdoors? Next, next item, works \\ outdoors? \\ R S1: Salesperson. \\ I T: Salesperson, and...? \\ R S1: Business person, business person. \\ R S2: Maybe actors. \\ F T: Yes, perform outdoors for their audience.
}

With regard to the feedback in Excerpt 13, the teacher expanded S2's answer by saying that actors may perform outdoors for their audience. Although the meaning was contextualized, there was no new information conveyed. Negotiated interaction, especially for meaning, is seldom found in such exchanges.

In this study, the students in the two listening classes had a severely restricted range of verbal functions to perform. They rarely initiated and seldom self-selected. However, most of the responses that the experienced teacher provided were comprehension checking and expansion in the prelistening stage, whereas the intern provided evaluations and repetitions. Therefore, most of the teachers' verbal activity was responded to and normally confined strictly to the turn of the initiator. The teacher determined the nature of the discourse and was particular about what freedom the students were afforded to construct their own utterances.

\title{
5.4 Features of the Listening Classes in this Study
}

Features of the two listening classes are summarized as follows. Pursuant to the particular teaching styles employed in the listening classes, both teachers adopted a process approach to form a listening cycle. This consisted of prelistening, while-listening, and postlistening phases. Most of the teachers' questions were asked in the prelistening phase to elicit responses from the students. Although the experienced teacher asked more wh-questions and the intern asked more Yes/No questions, these questions were short and usually limited to a single turn. The students had a very restricted range of verbal functions to perform. They rarely initiated or followed up. The discussion was teacher-led in nature.

\section{Conclusions and Pedagogical Implications}

In considering the three questions that guided this research, it can be inferred that the combination of these components has a valuable impact on listening classroom discourse. The first conclusion of this study was that the two listening classes were principally process-oriented. The two teachers used focused questions to guide students to develop their listening skills or strategies. I reached this conclusion based on my findings on the numerous guided questions asked in the prelistening and while-listening stages regarding the theme of 
the lesson.

The second finding was that the type of question most frequently asked by the experienced teacher was wh-questions and by the intern were Yes/No questions. However, both these types of questions failed to facilitate meaning negotiation. By their nature, Yes/No questions demand only decisions from students. However, wh-questions, in the experienced teacher's case, create pseudo-communication between the teacher and students; nonetheless, there are hardly any meaning negotiations between them. The majority of student turns are teacher-selected, and the conclusions of the teacher-student exchanges are also teacher-determined.

The final conclusion is that the functions of feedback used most often by the experienced teacher were comprehension checking and expansion, whereas the intern often provided evaluations and used repetition as feedback. The intern's listening class session was fast-paced. Students' comments were typically not elaborated upon, nor were the students asked to provide any analysis or explanation. The intern merely evaluated and repeated the students' answers.

As for the pedagogical implications of this study, it is hoped that this study will promote teachers' awareness of classroom discourse in language classes. Language teachers should pay extra attention to effectively modifying student responses, ask more follow-up questions on the significance of the texts, and promote more negotiated interactions in their classes.

\section{References}

Allwright, D., \& Bailey, K. M. (1991). Focus on the language classroom: An introduction to classroom research for language teachers. Cambridge: Cambridge University Press.

Allwright, D. (1988). Observation in the language classroom. London: Longman.

Au, K. (1980). Participation structures in a reading lesson with Hawaiian children: Analysis of a culturally appropriate instructional event. Anthropology and Education Quarterly, 11, 91-115. https://doi.org/10.1525/aeq.1980.11.2.05x1874b

Bakhtin, M. M. (1981). The dialogic imagination: Four essays by M.M. Bakhtin. Austin, TX: University of Texas Press.

Bakhtin, M. M. (1986). Speech genres and other late essays. Austin, TX: University of Texas Press.

Brock, C. (1986). The effects of referential questions on ESL classroom discourse. TESOL Quarterly, 20, 47-59. https://doi.org/10.2307/3586388

Chardron, C. (1988). Second language classrooms: Research on teaching and learning. Cambridge: Cambridge University Press.

Ellis, R. (1994). The Study of Second Language Acquisition. New York: Oxford Applied Linguistics.

Erickson, F., \& Shultz, J. (1981). When is a context? Some issues and methods in the analysis 
of social competence. In J. Green \& C. Wallaat (Eds.), Ethnography and language in educational settings (pp. 147-160). Norwood, NJ: Ablex.

Fairclough, N. (1989). Language and Power. London: Longman.

Fairclough, N. (1992). Interttextuality in critical discourse analysis. Linguistics and Education, 4, 269-293. https://doi.org/10.1016/0898-5898(92)90004-G

Flowerdew, \& Miller (2005). Second Language Listening: Theory and Practice. New York: Cambridge University Press.

Gall, M. D. (1970). The use of questioning in teaching. Review of Educational Research, 40, 707-721. https://doi.org/10.3102/00346543040005707

Gee, J. P. (1990). Social linguistics and literacies: Ideology in discourse. New York: Falmer.

Gee, J. P. (1992). The social mind: Language, ideology, and social practice. New York: Bergin \& Garvey.

Gumperz, J. (1982). Discourse strategies. New York: Cambridge University Press.

Halliday, M. A. K., \& Hasan, R. (1990). Language, context, and text. London: Oxford University Press.

Halliday, M. A. K. (1978). Language as social semiotic. London: Edward Arnold.

Harness-Goodwin, M. (1990). He-said-she-said: Talk as social organization among Black children. Bloomington, IN: Indiana University Press.

Hymes, D. (1974). Foundations in sociolinguistics: An ethnographic introduction. Philadelphia, PA: University of Pennsylvania Press.

Kearsley, G. P. (1976). Questions and question asking in verbal discourse: A cross-disciplinary review. Journal of Psycholinguistic Research, 5, 355-375. https://doi.org/10.1007/BF01079934

Larsen-Freeman, D. (1980). Discourse analysis in second language research. Rowley, MA: Newbury House.

Long, M. H., \& Sato, C. J. (1983). Classroom foreigner talk discourse: Forms and functions of teachers' questions. In H. W. Seliger \& M.H. Long (Eds.), Classroom oriented research in second language acquisition (pp. 268-286). Cambridge: Newbury House Publishers, Inc.

McHoul, A. (1978). The organization of turns a formal talk in the classroom. Language in Society, 7, 183-213. http://dx.doi.org/10.1017/S0047404500005522

Mehan, H. (1979). Learning lesson: Social organization in the classroom. Cambridge, MA: Harvard University Press.

Mehen, H. (1979). "What time is it, Denise?" Asking known information questions in classroom discourse. Theory into Practice, 18, 185-194. 
Mitchell, R. (1985). Process research in second language classrooms. Language Teaching, 18, 330-351.

Nong, B. C. (1993). Turn-taking in English classes: A case study and its implication (Unpublished master's thesis). National Taiwan Normal University, Taipei, Taiwan.

O’Connor, M. C., \& Michaels, S. (1999). Shifting participant frameworks: Orchestrating thinking practices in group discussion. In D. Hicks (Ed.), Discourse, learning, and schooling: Sociocultural and sociocognitive perspectives. New York: Cambridge University Press.

Pica, T., \& Long M. H. (1986). The linguistic and conversational performance of experienced and less experienced teachers. In R.R. Day (Ed.), Talking to learn: Conversation in second language acquisition (pp. 85-98). Rowley, MA: Newbury House.

Sinclair, J. M., \& Coulthard, R.M. (1975). Towards an analysis of discourse: The English used by teachers and pupils. London: Oxford University Press.

Sinclair, J. M., \& Brazil, D. (1982). Teacher talk. London: Oxford University Press.

Vygotsky, L. S. (1986). Thought and language. Cambridge, MA: MIT Press.

Vygotsky, L. S. (1987). Thinking and speech. New York: Plenum Press.

Wells, G. (1993). Reevaluating the IRF sequence: A proposal for the articulation of theories of activity and discourse for the analysis of teaching and learning in the classroom. Linguistics and Education, 5, 1-37. https://doi.org/10.1016/S0898-5898(05)80001-4

\section{Copyright Disclaimer}

Copyright for this article is retained by the author(s), with first publication rights granted to the journal.

This is an open-access article distributed under the terms and conditions of the Creative Commons Attribution license (http://creativecommons.org/licenses/by/3.0/). 